\title{
Past, Present, and Future of The Journal of Clinical Immunology, the International Journal of Inborn Errors of Immunity
}

\author{
Vincent R. Bonagura ${ }^{1,2,3,4}$ • Jean-Laurent Casanova 5,6,7,8,9 \\ Published online: 14 September 2020 \\ (C) Springer Science+Business Media, LLC, part of Springer Nature 2020
}

Dear Readers and Friends,

We write to share great news about the extraordinary rise of our Journal's impact factor (IF) that has risen from 4.13 in 2018 to 6.78 in 2019 [1]. We began our journey in 2013 [2], and refocused the JoCI as the International Journal for Inborn Errors of Immunity (IEI) [3]. Together, we gradually appointed a new board of elite and international Associate Editors, and expanded the full Editorial Board to reflect the diversity and international scope of the clinical and research community that cares for and studies children and adults with IEI. During the first 5 years of our tenure in leading the JoCI, sponsored by the CIS, we have added six supporting IEI Societies to the Journal, and we are in the process of adding an additional international IEI society in 2019 .

Vincent R. Bonagura

VBonagura@northwell.edu

Jean-Laurent Casanova

casanova@mail.rockefeller.edu

1 Laboratory of Host Defense, The Feinstein Institute for Medical Research, Manhasset, NY, USA

2 Division of Allergy and Immunology, Departments of Pediatrics and Internal Medicine, Great Neck, NY, USA

3 Donald and Barbara Zucker School of Medicine at Hofstra/ Northwell, Hempstead, NY, USA

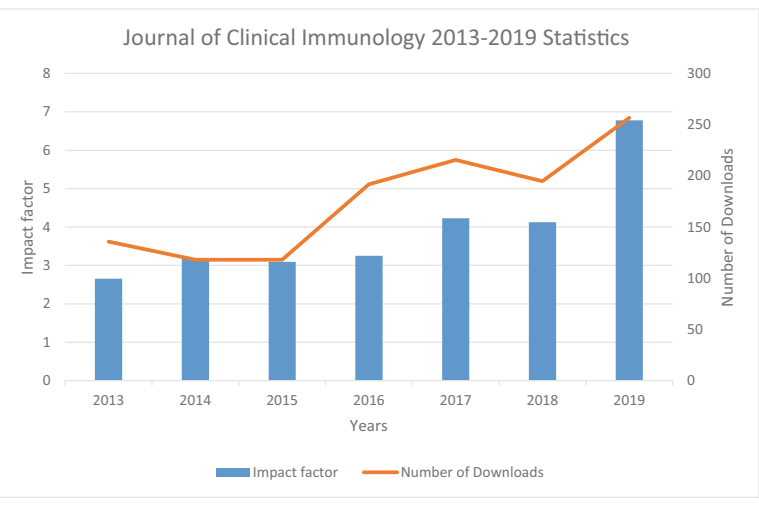

In 2013 , the IF of the JoCI was 2.83 which rose to 3.89 in 2015 , and over the past 7 years, there has been a steady

4 Steven and Alexandra Cohen Children's Medical Center of New York, Great Neck, NY, USA

5 St Giles Laboratory of Human Genetics of Infectious Diseases, Rockefeller Branch, The Rockefeller University, New York, NY, USA

6 Howard Hughes Medical Institute, New York, NY, USA

7 Laboratory of Human Genetics of Infectious Diseases, Necker Branch, INSERM U1163, Necker Hospital for Sick Children, Paris, France

8 University of Paris, Imagine Institute, Paris, France

9 Pediatric Hematology and Immunology Unit, Necker Hospital for Sick Children, AP-HP, Paris, France 
increase in the IF for the Journal (see accompanying figure). This year, there was a notable rise in the IF above 5 for the first time in the history of the journal. Collectively, we achieved this exceptional rise in our IF without distorting the content of the JoCI in favor of trendy or fashionable topics. We have only been guided by three principles: first, we have focused the journal on IEI; second, we have strived to improve the quality of the published papers; and third, we have published the very best work submitted to us as CME Reviews [4-7], How I Manage [8-10], and Original Articles [11-15], while having the community at large share their clinical experience in the format of Letters to the Editors [16-20].

Other sections, including Editorials [3, 21-26], In Memoriam [27-30], Commentaries [31-33], and Featured Articles [34, 35], and Conversations with Founders of the Field [36], have also helped make our journal the primary resource for international physicians and scientists who work in the field of IEI.

In 2019, our vision of having the JoCI break an IF "glass ceiling" of 5 was achieved with a comfortable margin to spare. We have set a new ceiling of 10 and are working diligently with our exceptional Associate Editors, and the expanded Editorial Board to make this vision becomes a reality in the years ahead. The addition of new IEI societies, to those that already support the JoCI, continues to be a goal for the future, as is publishing more high-quality manuscripts that we look forward to receive, read, and shepherd through the publication process in the years to come.

We continue our commitment to provide high-quality reviews of manuscripts we receive to help authors improve their research communications. Furthermore, we will continue to provide quick manuscript processing by our extraordinary and internationally recognized Editorial Board, to ensure that there is rapid publication of all finalized manuscripts. Furthermore, we will continue to develop new communication venues for the JoCI, to augment those already available to authors to broaden our support of the international clinical and research IEI community.

We express our warm thanks to the authors of the papers we have published in the JoCI over the years, the exceptional and hardworking Associate and extended Editorial Board, the Springer staff, and the reviewers who have provided their expertise in improving the manuscripts they have critiqued. Furthermore, we thank our readers for the enthusiastic responses about the manuscripts they have read over the past years. Our achievement in the Journal's IF could not have occurred without the cumulative support of all those who have labored incessantly to make this extraordinary achievement in our IF a reality.

Finally, the field of IEI is growing rapidly in multiple directions [37-40], and in response, we want the JoCI to play a key role in this development.
Onward and upward!

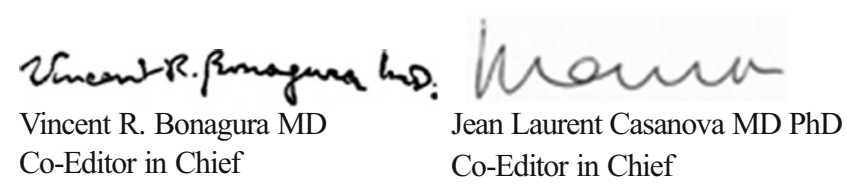

\section{References}

1. https://www.springer.com/journal/10875

2. http://archive.jsonline.com/business/pressrelease/national-pressreleases/clinical-immunology-society-appoints-vincent-bonaguramd-as-editorinchief-of-the-journal-of-clinical-immunology197229381.html

3. Casanova J, Bonagura V. Editorial. Editorial J Clin Immunol. 2018;38:445-6. https://doi.org/10.1007/s10875-018-0520-0.

4. Ravell JC, Chauvin SD, He T, Lenardo M. An update on XMEN disease. J Clin Immunol. 2020;40:671-81. https://doi.org/10.1007/ s10875-020-00790-x.

5. Booshehri LM, Hoffman HM. CAPS and NLRP3. J Clin Immunol. 2019;39:277-86. https://doi.org/10.1007/s10875-019-00638-z.

6. Heusinkveld LE, Majumdar S, Gao J, et al. WHIM syndrome: from pathogenesis towards personalized medicine and cure. J Clin Immunol. 2019;39:532-56. https://doi.org/10.1007/s10875-01900665-w.

7. Georgiev P, Charbonnier L, Chatila TA. Regulatory T cells: the many faces of Foxp3. J Clin Immunol. 2019;39:623-40. https:// doi.org/10.1007/s10875-019-00684-7.

8. Orange JS. How I manage natural killer cell deficiency. J Clin Immunol. 2020;40:13-23. https://doi.org/10.1007/s10875-01900711-7.

9. Kohn DB, Gaspar HB. How we manage adenosine deaminasedeficient severe combined immune deficiency (ADA SCID). J Clin Immunol. 2017;37:351-6. https://doi.org/10.1007/s10875017-0373-y.

10. Della-Torre E, Stone JH. "How I manage" IgG4-related disease. J Clin Immunol. 2016;36:754-63. https://doi.org/10.1007/s10875016-0331-0.

11. Bousfiha A, Jeddane L, Picard C, Al-Herz W, Ailal F, Chatila T, et al. Human inborn errors of immunity: 2019 Update of the IUIS Phenotypical Classification. J Clin Immunol. 2020;40:66-81. https://doi.org/10.1007/s10875-020-00758-x.

12. Bousfiha A, Jeddane L, Picard C, Ailal F, Bobby Gaspar H, al-Herz $\mathrm{W}$, et al. The 2017 IUIS phenotypic classification for primary Immunodeficiencies. J Clin Immunol. 2018;38:129-43. https:// doi.org/10.1007/s10875-017-0465-8.

13. Bousfiha A, Jeddane L, Al-Herz W, et al. The 2015 IUIS phenotypic classification for primary immunodeficiencies. J Clin Immunol. 2015;35:727-38. https://doi.org/10.1007/s10875-0150198-5.

14. Chovancova Z, Kralickova P, Pejchalova A, Bloomfield M, Nechvatalova J, Vlkova M, et al. Selective IgM deficiency: clinical and laboratory features of 17 patients and a review of the literature. J Clin Immunol. 2017;37:559-74. https://doi.org/10.1007/s10875017-0420-8

15. Rice GI, Melki I, Frémond M, et al. Assessment of type I interferon signaling in pediatric inflammatory disease. J Clin Immunol. 2017;37:123-32.

16. King JR, Hammarström L. Newborn screening for primary immunodeficiency diseases: history. Current and Future Practice J Clin 
Immunol. 2018;38:56-66. https://doi.org/10.1007/s10875-0170455-x.

17. Michniacki TF, Hannibal M, Ross CW, Frame DG, DuVall AS, Khoriaty R, et al. Hematologic manifestations of deficiency of adenosine deaminase 2 (DADA2) and response to tumor necrosis factor inhibition in DADA2-associated bone marrow failure. J Clin Immunol. 2018;38:166-73. https://doi.org/10.1007/s10875-0180480-4.

18. Greil C, Roether F, La Rosée P, et al. Rescue of cytokine storm due to HLH by hemoadsorption in a CTLA4-deficient patient. J Clin Immunol. 2017;37:273-6. https://doi.org/10.1007/s10875-0170377-7.

19. Brigida I, Chiriaco M, Di Cesare S, et al. Large deletion of MAGT1 gene in a patient with classic Kaposi sarcoma, CD4 lymphopenia, and EBV infection. J Clin Immunol. 2017;37:32-5. https://doi.org/ 10.1007/s10875-016-0341-y.

20. Delmonte OM, Biggs CM, Hayward A, Comeau AM, Kuehn HS, Rosenzweig SD, et al. First case of X-linked Moesin deficiency identified after newborn screening for SCID. J Clin Immunol. 2017;37:336-8.https://doi.org/10.1007/s10875-017-0391-9.

21. Goto F, Uchiyama T, Nakazawa Y, Imai K, Kawai T, Onodera M. Persistent impairment of T-cell regeneration in a patient with activated PI3K $\delta$ syndrome. J Clin Immunol. 2017;37:347-50. https:// doi.org/10.1007/s10875-017-0393-7.

22. Bonagura VR. Successful rituximab treatment for lymphoma, secondary immunodeficiency causing debilitating sinusitis: underlying primary immunodeficiency disease, and alternative treatments to improve the quality of life? J Clin Immunol. 2019;39:229-30. https://doi.org/10.1007/s10875-019-00636-1.

23. Casanova J, Bonagura V. Editorial. Journal of Clinical Immunology J Clin Immunol. 2019;39:751-2. https://doi.org/10. 1007/s10875-019-00699-0.

24. Bonagura VR, Casanova J. Editorial for JoCI. Editorial for JoCI $J$ Clin Immunol. 2015;35:519-20. https://doi.org/10.1007/s10875015-0181-1.

25. Announcement. J Clin Immunol 34, 891 (2014). https://doi.org/10. 1007/s10875-014-0108-2

26. Bonagura VR, Casanova J, Rosenthal DW. A note from the editorin-chief, deputy editor, and managing editor. J Clin Immunol. 2015;35:97. https://doi.org/10.1007/s10875-015-0143-7.

27. Fleisher TA, Orange JS. William T. Shearer MD PhD in Memoriam. J Clin Immunol. 2018;38:833-5. https://doi.org/10. 1007/s10875-018-0571-2.

28. Aiuti A, Quinti I. In memoriam: Fernando Aiuti, MD (June 8, 1935-January 9, 2019). J Clin Immunol. 2019;39:142-3. https:// doi.org/10.1007/s10875-019-00605-8.

29. Condino-Neto A. Prof. Dr. Beatriz Tavares Costa-Carvalho obituary. J Clin Immunol. 2019;39:529. https://doi.org/10.1007/s10875019-00655-y.
30. Lankester A, Heidt P, Rümke H, Bredius R, van Tol M. In memoriam: Prof. Dr. J.M.J.J. Vossen (1937-2019). J Clin Immunol. 2019;39:530-1. https://doi.org/10.1007/s10875-01900668-7.

31. Su HC, Orange JS. The growing spectrum of human diseases caused by inherited CDC42 mutations. J Clin Immunol. 2020;40: 551-3. https://doi.org/10.1007/s10875-020-00785-8.

32. Meyts I. Hematopoietic stem cell transplantation in CARD9 deficiency: knight in shining armor? J Clin Immunol. 2019;39:459-61. https://doi.org/10.1007/s10875-019-00660-1.

33. Bonagura VR. Successful rituximab treatment for lymphoma, secondary immunodeficiency causing debilitating sinusitis: underlying primary immunodeficiency disease, and alternative treatments to improve the quality of life? J Clin Immunol. 2019;39:229-30. https://doi.org/10.1007/s10875-019-00636-1.

34. Verboon JM, Mahmut D, Kim AR, Nakamura M, Abdulhay NJ, Nandakumar SK, et al. Infantile myelofibrosis and myeloproliferation with CDC42 dysfunction. J Clin Immunol. 2020;40:554-66. https://doi.org/10.1007/s10875-020-00778-7.

35. Queiroz-Telles F, Mercier T, Maertens J, Sola CBS, Bonfim C, Lortholary O, et al. Successful allogenic stem cell transplantation in patients with inherited CARD9 deficiency. J Clin Immunol. 2019;39:462-9. https://doi.org/10.1007/s10875-019-00662-z.

36. Buckley RH. Conversations with founders of the field of human inborn errors of immunity. J Clin Immunol. 2020;40:1-8. https:// doi.org/10.1007/s10875-019-00736-y.

37. Notarangelo LD, Bacchetta R, Casanova JL, Su HC. Human inborn errors of immunity: an expanding universe. Sci Immunol. 2020 Jul 10;5(49):eabb1662. https://doi.org/10.1126/sciimmunol. abb1662

38. Casanova JL, Abel L. Science. Primary immunodeficiencies: a field in its infancy. 2007 Aug 3;317(5838):617-9. https://doi.org/10. 1126/science.1142963.

39. Bousfiha A, Jeddane L, Picard C, Al-Herz W, Ailal F, Chatila T, et al. Human inborn errors of immunity: 2019 update of the IUIS Phenotypical Classification. J Clin Immunol. 2020 Jan;40(1):6681. https://doi.org/10.1007/s10875-020-00758-x.

40. Tangye SG, Al-Herz W, Bousfiha A, Chatila T, CunninghamRundles C, Etzioni A, et al. Human inborn errors of immunity: 2019 update on the classification from the International Union of Immunological Societies Expert Committee. J Clin Immunol. 2020 Jan;40(1):24-64. https://doi.org/10.1007/s10875-019-00737-x.

Publisher's Note Springer Nature remains neutral with regard to jurisdictional claims in published maps and institutional affiliations. 